\title{
Analysis of Marketing Kampung Super Strategy in Grobogan District
}

\section{Dwi Sunarti ${ }^{1}$, Bambang Mulyatnoํㅜㄹ Elisa Anindyawati ${ }^{2}$}

Master of Agribusiness, Faculty of Animal Husbandry and Agriculture Diponegoro University Email: elisaanindyawati@gmail.com

${ }^{1}$ Teaching Staff of the Faculty of Animal Husbandry and Agriculture, Diponegoro University

${ }^{2}$ Post-graduate students, Faculty of Animal Husbandry and Agriculture, Diponegoro University

\begin{abstract}
Indonesia's natural wealth is very abundant and various kinds of biodiversity become one of the supporting factors in fulfilling protein needs in the livestock subsector. Farmers choose the type of Super Village Chicken because the harvest period is faster (45-60 days), provides sufficient income, relatively low mortality rates, savings in maintenance and feed costs. The large population of Kampung Super Chicken farms in Grobogan Regency causes breeders difficulties in marketing chicken, so the sale price in the farm is unstable. This price instability does not dare to take larger scale chicken seeds. The method used in this study is the survey method. The number of samples is 60 respondents. The reason for the sample is 60 because there are 6 farmer groups in Grobogan Regency, each with 10 members. Tracer traders use the snow ball method from farmers and the marketing institutions involved.

The data analysis included descriptive analysis to determine the business income at the farmer level and SWOT Analysis to find out the Super Village Chicken Marketing Strategy in Grobogan Regency.

Based on the results of the discussion, conclusions can be drawn as follows: (1) Marketing efficiency below 50\% is said to be efficient, (2) Factors that encourage and inhibit marketing of Super Vill age Chicken are fluctuating chicken prices, difficult marketing efforts, capital business is relatively limited, lack of knowledge of farmers, (3) Marketing strategy that should be done to improve the marketing of super chicken in Grobogan Regency is to cooperate with other parties in partnership, conduct transactions directly with buyers, make breakthroughs by selling in supermarkets, providing business cutting chicken, selling to big collectors, innovating various chicken products.
\end{abstract}

Keywords - Kampung Chicken Super, SWOT, Marketing Strategy.

\section{INTRODUCTION}

Indonesia's natural wealth is very abundant and various kinds of biodiversity become one of the supporting factors in fulfilling protein needs in the livestock subsector. Meeting the needs of animal protein from poultry products must be balanced with an increase in the population of poultry, so that products from livestock, especially poultry, are able to meet the needs of animal protein of all Indonesian people. Poultry farming in Indonesia has an important role in livestock development as fulfilling animal food needs. At present poultry in Central Java contributes to meat production, which is $16.13 \%$ then followed by beef at $6.28 \%$. Of the total number of poultry, around $9.05 \%$ is provided by broiler chickens and only around $7.08 \%$ is provided by local chickens, the remainder is by other poultry types (Statistics of Animal Husbandry and Animal Health in Central Java Province, 2017). High demand for poultry is due to the price of chicken meat which tends to be cheap and easy to obtain.

Many people today choose products that are ASUH (Safe, Healthy, Whole, and Halal) by choosing local poultry as a fulfillment of animal protein needs, but the high demand is not comparable with the existing population. This inadequate population is due to a long maintenance time for local chickens. At present in addition to broiler chicken, which has a short maintenance time, there are also native chickens, which have a short maintenance time, namely Super Chicken. Super hens are native chickens originating from the cross between laying hens and native chickens. The innovation of the discovery of super chicken was due to the large number of farmers who complained about the length of time they enjoyed the results of native chicken farming. In addition to a short maintenance time of only 2 months, Super Chicken Chicken is also low in cholesterol like ordinary kampung chicken with 4 months maintenance. At present Grobogan 
Regency produces Super Village Chicken with its marketing still in the local area. The Super Village Chicken Business faces strong competition, because almost every sub-district has a Super-Chicken Village breeder. Farmers choose the type of Super Village Chicken because the harvest period is faster (45-60 days), provides sufficient income, relatively low mortality rates, savings in maintenance and feed costs. The large population of Kampung Super Chicken farms in Grobogan Regency causes breeders difficulties in marketing chicken, so the sale price in the farm is unstable. This price instability does not dare to take larger scale chicken seeds

The marketing process that is too long makes farmers become anxious in chicken farming because the prices obtained by farmers are getting lower. This increasingly fierce competition requires farmers to implement appropriate marketing strategies in competition in order to obtain high marketing efficiency. This is based on a strategy to maximize strength and business opportunities, while at the same time minimizing existing weaknesses and threats so as to obtain higher income.

Research needs to be done with the aim to find out what factors drive and hinder the marketing of Super Village Chicken and what marketing strategies should be done to improve the marketing of Super Village Chicken. The results of the study will be obtained by factors that encourage and inhibit and what marketing strategies are carried out to facilitate marketing of Super Village Chicken in Grobogan Regency, so that it can be beneficial for farmers to improve marketing. The right marketing strategy is useful for overcoming increasingly fierce market competition, therefore research will be carried out with the title "Analysis of the Super Village Chicken Marketing Strategy in Grobogan Regency".

\subsection{Super Chicken Village}

\section{LITERATURE REVIEW}

Super Kampung Chicken is a result of a crossbred chicken (male) using Bangkok Chicken, Pelung Chicken, Kedu Chicken, with laying-type chicken (female). The crossing aims to get the type of Kampung Chicken which has high productivity of meat and eggs, thus the cultivation of Super Village Chicken is more profitable because it can be harvested with a shorter time. ) so as to produce fertile eggs then Super Kampung chickens are hatched by using incubators (hatching machines). According to Jarmani et al. (2016) said that silangan chicken (F1) from local roosters (free-range chicken, kedu chicken, pelung chicken, and bangkok chicken) with laying hens had criteria according to consumer demand, namely weight $0.9-1.0 \mathrm{~kg}$ can be achieved at the age of 12 weeks, it looks like a real local chicken with black feathers and yellow skin.

\subsection{Super Chicken Maintenance System}

The success in raising or running a Super Kampung Chicken is influenced by the effective and efficient maintenance system of Kampung Ayam. Maintenance for 2-2.5 months with an average weight of 0.9-1.5 kg must choose quality seeds and mixtures at affordable prices.'

\subsection{Business Costs for Super Chicken Village Business}

Production costs are costs of compensation received by the owners of production factors, or costs incurred by farmers in the production process, both in cash and non-cash (Daniel, 2002). Soekartawi (2014) states that production costs are the value of all production factors used, both in the form of objects and services during the production process. So me concepts about costs such as: variable costs, fixed costs, and total costs. Variable costs are variable costs caused by changes in the amount of results. If the amount of goods produced increases, the variable cost also increases. Variable costs charged to each unit are called average variable costs (Herlambang, 2002). Fixed costs are constant costs for each level / number of results produced. Fixed costs charged to each unit are called average fixed costs.

\subsection{Marketing channel}

Suharno (2017) stated that marketing channels at chicken farms, both chicken and domestic chicken, are generally long. This is because the marketing channel starts from collectors' breeders, chicken bases to cutters, retailers and new customers. Every stage of the distribution has a fee, so that the thinner the possibility of the farmer to get a reasonable profit. The marketing channel needs to be shortened to minimize the difference in prices that occur at the farmer level and at the consumer level. The size of marketing costs is very dependent on the size of the activities of marketing institutions and facilities needed. Marketing costs also depend on the length of the marketing chain involved. The size of the marketing margin is influenced by changes in marketing costs, profit from intermediary traders, prices paid by end consumers and prices received by producers. Besides these factors the magnitude of the marketing margin is also influenced by the distance between the producer region and the consumer and the nature of the goods as a whole will increase marketing costs (Purmantono, 1993). 


\subsection{Marketing strategy}

Current competition makes business people / companies must use marketing strategies that are truly appropriate to achieve their intended goals or to maintain the continuity of their business. The purpose of this marketing activity is to influence consumers to be willing to buy goods or services produced by a company when they need it. Companies must be able to understand the desires or demands of the needs of consumers, and know the marketing strategies that must be done in order to achieve the desired goals.

According to Wawan (2016) marketing strategy is the organization of all the resources owned to market a product which is then mentioned in the marketing strategy that must be done by taking into account the marketing mix, product life cycle, and maintaining or extending the stage of market maturity.

\section{RESEARCH GAP}

The results of this study support or in accordance with the research conducted by Novianto (2015) on Analysis of Marketing Strategies to Increase Sales of Super Village Chicken (Jambon Village, Jambon District, Ponorogo Regency). thesis, Muhammadiyah Ponorogo. University. Increasingly intense business competition requires every entrepreneur to maintain its existence. With the increasingly fierce competition, it is now demanded to implement appropriate marketing strategies that can be used as weapons in the competition war between entrepreneurs. Marketing strategy is a plan that describes the company's expectations of the impact of various activities or marketing programs on the demand for products or product lines in certain target markets.

It also supports the research conducted by Turnip (2016) which states that the IE matrix results show that the business is in Hold and Maintain (V) position and the strategy that is suitable for this position is the strategy of market penetration and product development. The SWOT Analysis of the Indonesian Christian Community Development Training Center institution produced seven alternative strategies related to the company's position in the IE matrix. The order of priority strategies is (1) Carry out creative advertising and sales promotion (TAS value $6.64)$, (2) maintain product quality (TAS value 6.50), (3) Increase production volume (TAS value 6.23), (4) Trying an organic certificate label (TAS value of 5.75), (5) Market penetration (TAS value of 5.43), (6) Product development (TAS value of 5.40), (7) Improving product image (positioning) (TAS value of 5.28).

\section{RESEARCH METHODS}

The method used in this study is the survey method. The number of samples is 60 respondents. The reason for the sample is 60 because there are 6 farmer groups in Grobogan Regency, each with 10 members. Tracer traders use the snow ball method from farmers and the marketing institutions involved. The data analysis included descriptive analysis to determine the business income at the farmer level and SWOT Analysis to find out the Super Village Chicken Marketing Strategy in Grobogan Regency.

\section{THINKING FRAMEWORK}

Kampung chicken has a very important role in improving community nutrition and in increasing income. Currently the production of Kampung Super Chicken in Grobogan Regency is highly developed, but as the production of Super Kampung Chicken grows, chicken farmers experience difficulties in marketing. The marketing process that is too long makes the farmers become anxious in their chicken business because the prices of farmers are getting lower. Research on what factors are driving and inhibiting the marketing of Super Village Chicken and marketing strategies needs to be done to find out what should be done to improve the marketing of Super Village Chicken. From th is it will be obtained the factors that encourage and inhibit and what marketing strategy is done to facilitate marketing of Super Village Chicken in Grobogan Regency, so that it can be beneficial for farmers to increase marketing.

\section{RESULTS AND DISCUSSION}

The marketing pattern that has been used by the super chicken farmers in Grobogan Regency is a marketing pattern in general, which is sold to end consumers (live chickens) with farmer marketing, one trader, two traders, three traders and consumers. The results of the calculation show that:

MP = Consumer Price (Rupiah) - Buy Price of Breeder (Rupiah)

$\mathrm{MP}=32.300-21.200$

$\mathrm{MP}=11.100$

Farmer Share $=$

Price of Buy Breeder (Rupiah) x 100\%

Consumer Price (Rupiah)

Farmer Share $=\underline{21.200} \times 100 \%$

32.300

$=65,63 \%$

(complete calculation see Appendix)

Because the value is above $50 \%$ it is said to be efficient. 


\section{Discussion}

Based on the results of the analysis it can 1 seen that the EFAS matrix shows that weakness weakness is higher than strength, so it is necessary to $\mathrm{u}_{\mathrm{i}}$ strategies to overcome them. From the results of $\mathrm{tl}$ SWOT analysis several strategies can be combined sur as strategies that combine:

1) Strengh and Opportunity (strategy) implementing a maintenance system and effectis maintenance time will make various groups like to meet the high demand for using low cholester ${ }_{6}^{4}$ in super chickens that will benefit livestor business.

2) WO strategy (a combination of weakness opportunity), namely the availability of superfoc raw materials that will adequately increa: demand, the grade of super chicken will produ। low cholesterol that many consumers like an become an added value, the marketing system $\mathrm{f}_{\mathrm{r}}$ superchicken is preferred by various groups .

3) ST strategy, namely a combination of strength ar threat, such as supply from outside the distri which will smoothly increase the availability 1 super chicken market, continuous production

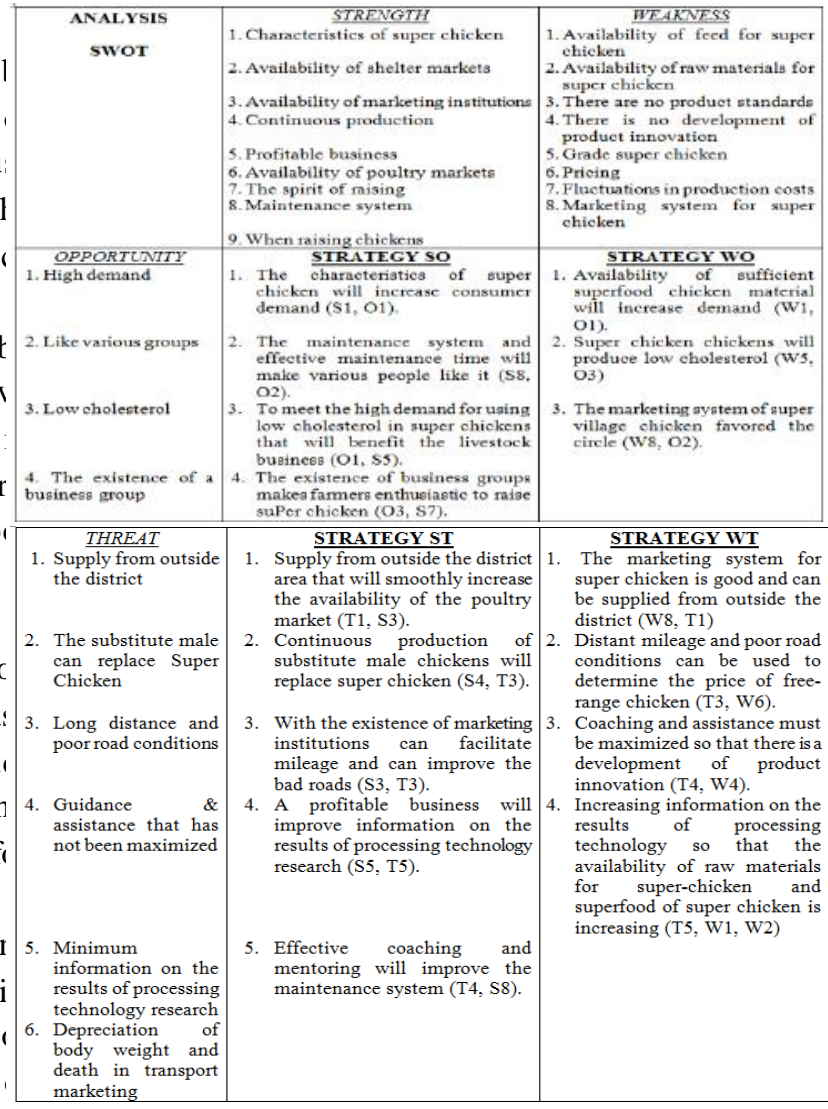
substitute male chickens will replace super chicken, with the presence of marketing institutions can facilitate mileage and improve roads the bad, profitable business will improve information on the results of processing technology research, coaching and mentoring that will effectively improve the maintenance system.

4) Weak-threat combination strategy, which is a super chicken chicken marketing system that can supply from outside the regency, guidance and assistance must be maximized so that there is product innovation development, improving information technology research results so that raw chicken and chicken feed are available. super village is increasing. Besides that, it can also use social media as a promotional event so that the sales of super chicken will increase because now is the era of globalization that uses all-sophisticated internet, so that with minimal promotion costs it will be able to reach an increasingly broad market share.

This is in line with the marketing strategy through SWOT analysis (Rangkuti, 2009) because with the SWOT analysis (Strength, Weaknesses, Opportunities, Threats) can evaluate opportunities and challenges in the agribusiness environment. The results of the SWOT matrix will make it easier to formulate various strategies that need to or should be carried out by super chicken farmers.

The results of this study support or in accordance with the research conducted by Novianto (2015) on Analysis of Marketing Strategies to Increase Sales of Super Village Chicken (Jambon Village, Jambon District, Ponorogo Regency). thesis, Muhammadiyah Ponorogo University.

Increasingly tight business competition requires every businessman to maintain its existence. With the increasingly fierce competition, it is now demanded to implement appropriate marketing strategies that can be used as weapons in the competition war between entrepreneurs. Marketing strategy is a plan that describes the company's expectations of the impact of various activities or marketing programs on the demand for products or product lines in certain target markets. There are marketing programs (such as advertising, sales promotions, personal selling, customer service, or product development) that have different effects on demand. For this reason, super chicken entrepreneurs in Jambon 
Village, Jambon District, Ponorogo Regency must have new strategies to find out the positive and negative aspects, namely by using a SWOT analysis to formulate a new marketing strategy. The SWOT analysis is an identification of external and internal factors and strategies that reflect the comparis on between the two.

This is based on the logic that an effective strategy is to maximize strength and business opportunities, but at the same time minimize existing weaknesses and threats. The workings of the SWOT analysis here use a matrix by including internal environmental factors (IFAS) and include external environmental factors in vertical cells in the form of opportunities and threats that can be known from the results of external environmental analysis (EFAS). Then from the remain ing cells that meet iv between internal and external factors, we can find out the alternative strategies produced by the SWOT analysis. Aggressive strategies or expansion (based on SWOT analysis) and super chicken business in Jambon Village, Jambon District, Ponorogo Regency have alternative hold and design strategies or maintain and maintain strategies (based on IE Matrix analysis). This strategy can be carried out by maximizing internal and external strengths and taking advantage of existing opportunities.

It also supports the research conducted by Turnip (2016) which states that the IE matrix results show that the business is in Hold and Maintain (V) position and the strategy that is suitable for this position is the strategy of market penetration and product development.

The SWOT Analysis of the Indonesian Christian Community Development Training Center institution produced seven alternative strategies related to the company's position in the IE matrix. The order of priority strategies is (1) Carry out creative advertising and sales promotion (TAS value 6.64), (2) maintain product quality (TAS value 6.50), (3) Increase production volume (TAS value 6.23), (4) Try ing an organic certificate label (TAS value of 5.75), (5) Market penetration (TAS value of 5.43), (6) Product development (TAS value of 5.40), (7) Improving product image (positioning) (TAS value of 5.28).

Table 4.7. The average selling price offarmers, traders and consumers and MP

\begin{tabular}{|c|c|c|c|c|c|}
\hline Respondents & $\begin{array}{l}\text { Selling Prices } \\
\text { ofFamers I }\end{array}$ & \begin{tabular}{|l} 
Selling price \\
of trader I. \\
Trader II \\
\end{tabular} & $\begin{array}{l}\text { Selling price } \\
\text { of trader II- } \\
\text { trader III }\end{array}$ & 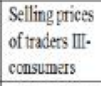 & Average \\
\hline \begin{tabular}{|l} 
AIERAGE \\
\end{tabular} & 21.200 & Rp 23.890 & RP $\quad 26.600$ & R甲 $\quad 32.100$ & Rp 25.925 \\
\hline $\begin{array}{l}\text { Difference } \\
\text { (Marketing } \\
\text { Margin) }\end{array}$ & & Rq2.600 & Rq2.800 & Rp5.500 & Rp3.633 \\
\hline
\end{tabular}

Based on table 4.7, it is known that the price of the farmer, the purchase price of the trader I and the purchase price of the trader II and the consumer the average selling price of the farmer is Rp.21,200 and for the purchase price $I$ is $\mathrm{Rp} 23,800$, and the average purchase price is Rp.26,600 to consumers in the amount of Rp. 32,100. The survey was conducted on 60 respondents and from the data it was found that the marketing margins of each trader averaged Rp3,633.

In addition, it is also consistent with the research conducted by Ekapriyatna (2016) which aims to determine the internal conditions, external conditions of broiler farms and strategies that must be determined by employers based on SWOT analysis. This research uses qualitative research design. The subject of this study was the owner of the Ananta Guna broiler farm in Sidan Village, and the object of this study was a business development strategy. Data collection techniques used the interview method, then analyzed using the IFAS and EFAS methods. The results of the study show that internal environmental conditions in the form of strength, namely high-quality products, affordable prices, use direct distribution channels. The results of this study are also consistent with the research conducted by Aedah et al (2016) which states that the poultry industry in Indonesia has often experienced ups and downs in recent years. The vulnerability of broiler businesses to various turmoil opens opportunities to develop local poultry businesses such as free-range chicken, which is currently increasing in popularity compared to other poultry meat. Also consistent with the research conducted by Haryono et al. (2015) which states that the Java Super Chicken Business Industry can increase income and is a new business opportunity that is prospective to be developed, super chicken livestock business can fulfill chicken meat as a need for local animal protein.

\section{Conclusion}

Based on the results of the analysis and discussion, conclusions can be drawn as follows:

1. Marketing efficiency above $50 \%$ is said to be efficient.

2. Factors that encourage and hinder the marketing of Super Kampung Chicken are fluctuating chicken prices, difficult marketing efforts, relatively limited business capital, lack of knowledge of farmers.

3. The marketing strategy that should be carried out to improve the marketing of super chicken in Grobogan Regency is to work with other parties in partnership, conduct transactions directly with 
buyers, make breakthroughs by selling at supermarkets, provide chicken slaughter business, sell to large collectors, innovating various chicken products

\section{Recomendati on}

Suggestions that can be put forward in this study are:

1. It is best for farmers to apply the right marketing strategy through social media, work with big collectors, make a breakthrough by selling in supermarkets, providing chicken slaughter business, innovating various chicken products to increase sales.

2. In future research with similar topics can be compared with chicken farmers in other locations or using quantitative analysis.

\section{REFERENCES}

[1] Aedah, Siti., Bintoro, Djoefrie, Dan Gendut Suprayitno. 2016. Faktor-Faktor Yang Memengaruhi Daya Saing Industri Unggas Ayam Kampung (Studi Kasus PT Dwi Dan Rachmat Farm, Bogor). Manajemen IKM, September 2016 (173-182)

[2] Daniel. M., 2002. Metode Penelitian Sosial Ekonomi. Bumi Aksara. Jakarta.

[3] Data Statistik Dinas Peternakan dan Kesehatan Hewan Provinsi Jawa Tengah, 2017

[4] Ekapriyatna, I D.G.B. 2016. Analisis Strategi Pengembangan Usaha Peternakan Ayam Pedaging (Broiler) Ananta Guna Di Desa Sidan Kecamatan Giany ar Kabupaten Gianyar. Jurnal Program Studi Pendidikan Ekonomi (JPPE).

[5] Haryono., Radna, Pambudhi., Dan Muna Chanifia. 2015. Peternakan Ayam Jawa Super Delima Kedaton (Dengan Lima Profit Keuntungan Dan Toko Online). Jurnal Penelitian.

[6] Herlambang, T. 2002. Ekonomi Manajerial dan Stategi Bersaing. PT. Raja Grafindo Perseda, Jakarta

[7] Jarmani, S.N., R. Dharsana, W.K. Sejati, E.Basuno and B. Wibowo. 2016. Crossbredof ay am kampung as an effort to meet the consumers need of ayam kampung in the future. Bulletin of animal Science, Supplement Edition:427-431.

[8] Novianto, Dian Aris. 2015. Analisis Strategi Pemasaran untuk Meningkatkan Penjualan Ayam Kampung Super (Desa Jambon Kecamatan Jambon Kabupaten Ponorogo). Skripsi Universitas Muhammadiy ah Ponorogo

[9] Rangkuti, Freddy. 2009. Analisis SWOT Teknik Membedah Kasus Bisnis. PT. Gramedia Pustaka Utama. Cetakan ke enambelas, Jakarta.

[10] Soekartawi. 2014. Teori Ekonomi Produksi. Dengan Pokok Bahasan Analisis Fungsi. Cobb- Douglas. PT. Raja Grafindo Persada, Jakarta.

[11] Turnip, D.S.M. 2016. Analisis Strategi Pemasaran Berday a Saing Pada Produk Ayam Kampung Organik ( Studi Pada Lembaga Pusat Pelatihan Pengembangan
Masyarakat Huria Kristen Indonesia). Jurnal Niaga \& Bisnis

[12] Purmantono, E. 1993. Tataniaga Ayam Ras Pedaging pada Peternak Kecil di Kabupaten Bogor. Fakultas Peternakan, Institut Pertanian Bogor.

[13] Wawan P, 2016. Strategi Produk, Pemberian Merek dan Pelayanan Konsumen. Pemasaran Strategi Modul 10Pengembangan Merek. Pusat Pengembangan Bahan Ajar Universitas Mercubuana. Jakarta. 